\title{
Influence of air quenching on apparent hardness of valve seat inserts obtained with AISI M2 high-speed steel powder
}

\author{
Gomes, M. P. ${ }^{1 *}$; Santos, I. P. ${ }^{1}$; Reis, L. A. M. ${ }^{1}$; Cione, F. C. ${ }^{1}$; Colosio, M. A²; Rossi, J. L. ${ }^{1}$ \\ 1 Instituto de Pesquisas Energéticas e Nucleares, IPEN - CNEN, São Paulo, SP, Brazil. \\ 2 General Motors do Brasil, São Caetano do Sul, SP, Brazil. \\ *e-mail:m_gomes@outlook.com
}

\begin{abstract}
The aim of this work consisted of evaluate the influence of heat treatment on sintered valve seat inserts (VSI) obtained with the AISI M2 high-speed steel powder. The AISI M2 high-speed steel powder was mixed with iron powder and additives such as manganese sulphide, zinc stearate, graphite and carbides. The heat treatment of the VSI consisted of air quenching followed by double tempering it in seven different equidistant temperatures, from $100^{\circ} \mathrm{C}$ until $700^{\circ} \mathrm{C}$. The mechanical property was measured regarding the VSI apparent hardness. The results indicated that the VSI obtained with the AISI M2 high-speed steel powders mixtures showed the best results regarding its apparent hardness after air quenching and double tempering it at $600^{\circ} \mathrm{C}$.
\end{abstract}

Keywords: powder metallurgy, air quenching, valve seat insert, AISI M2 high-speed steel.

\begin{abstract}
Resumo
O objetivo deste trabalho consistiu em avaliar a influência do tratamento térmico em insertos de assentos de válvulas (do inglês valve seat insert, VSI) obtido com o pó de aço rápido AISI M2. O pó de aço rápido AISI M2 foi misturado com pó de ferro e aditivos como o sulfeto de manganês, estearato de zinco, grafite e carbetos. O tratamento térmico dos VSI consistiu em temperá-los ao ar e duplamente revení-los em sete temperaturas equidistantes diferentes, de $100{ }^{\circ} \mathrm{C}$ a $700{ }^{\circ} \mathrm{C}$. A propriedade mecânica foi medida em relação à dureza aparente dos $\mathrm{VSI}$. Os resultados indicaram que o VSI obtido com a mistura de pós do aço rápido AISI M2 obtiveram os melhores resultados em relação à sua dureza aparente depois de temperados ao ar e duplamente revenidos a $600{ }^{\circ} \mathrm{C}$.
\end{abstract}

Palavras-chave: metalurgia do pó, têmpera ao ar, inserto de assento de válvula, aço rápido AISI M2.

\section{Introduction}

Automobile engines have undergone substantial changes, which have resulted in increased performance, reduced fuel consumption and environmental impact [1]. The mechanical set responsible for partially sealing the combustion chamber is constituted of valve seat and valve seat insert (VSI), as shown in Fig. 1.

The powder metallurgy $(P / M)$ is a near-net shape manufacturing process that combines the features of shape-making technology for powder compaction with the development of final material and design properties (physical and mechanical) during subsequent densification or consolidation processes, e.g., sintering [2].

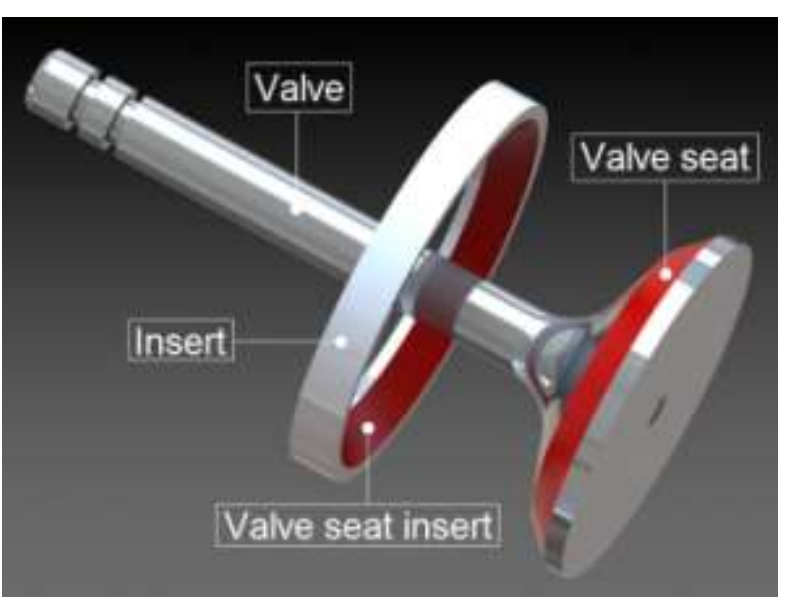

Figure 1. Drawing in perspective of the valve seat and valve seat insert positioning. 
The VSI studied at the present work was previously developed by Santos et al. [3-5], and a deep research was based on the as sintered component. One of the main targets of this work was to heat treat and characterize such VSI obtained with powders mixture of AISI M2 high-speed steel, iron, and others additives. The heat treatment consisted of air quenching and double tempering all the components. As any temperature up to the lower critical may be used for tempering [6], all air quenched VSI were double tempered at seven equidistant temperatures, from 100 ${ }^{\circ} \mathrm{C}$ until $700{ }^{\circ} \mathrm{C}$.

\section{Materials and methods}

The VSI were obtained from a mixture of powders. The powders mixtures consisted of HSS type AISI M2 plus iron powder and others additives such as manganese sulphide, niobium carbide, graphite and zinc stearate to reduce the die-wall friction.

All the powders were mixed in an intensive mixer for $300 \mathrm{~s}$ at $1,715 \mathrm{rpm}$, except copper because it was added by metallic infiltration, i.e., two compacts were pressed from the iron powders mixtures and cooper and before the sintering process took place, these two compacts had to be put together, to mount one on top of the other.

Green compacts were obtained from the powders mixtures after compaction in a double action automated hydraulic press. The compaction was attained at a pressure of $700 \mathrm{MPa}$. The manufactured VSI from this process with dimensions of $32.5 \times 25.5 \times$ $5.9 \mathrm{~mm}^{3}$.

The compacted VSI was pre-heated up to 600 ${ }^{\circ} \mathrm{C}\left(0.275^{\circ} \mathrm{C} / \mathrm{s}\right)$ for $2,100 \mathrm{~s}$ to ensure the whole zinc stearate elimination. Then, it was sintered at $1,150{ }^{\circ} \mathrm{C}$ $\left(0.228{ }^{\circ} \mathrm{C} / \mathrm{s}\right)$ for $2,400 \mathrm{~s}$. Finally, the VSI was cooled until room temperature with a rate of $0.335^{\circ} \mathrm{C} / \mathrm{s}$. The sintering process have been performed in a continuous commercial belt furnace under a hydrogen-based $(90 \%$ $\mathrm{H}_{2}+10 \% \mathrm{~N}_{2}$ ) atmosphere.

The sintered VSI heat treatment consisted of austenitizing it at $1,150{ }^{\circ} \mathrm{C}$ (heated at a rate of 0.480 ${ }^{\circ} \mathrm{C} / \mathrm{s}$ ) for $1,200 \mathrm{~s}$ in a laboratory muffle. In order to avoid, or at least minimize decarburization, the inserts were wrapped in a blick white sulphite drawing paper and put inside a cast iron box containing a mixture of $50 \% \mathrm{C}$ (graphite) $+50 \% \mathrm{Al}_{2} \mathrm{O}_{3}$ (aluminum oxide). This box was then put inside the muffle for heat treatment. $A$ thermocouple type $\mathrm{k}$ was attached to the samples and a data acquisition system was used to measure the cooling rate of the VSI samples. The austenitized samples were at this time, air quenched until room temperature. The quenched components were subjected to a subcritical heat treatment referred to as tempering, in a similarly way as used for the air quenching. All air quenched VSI were double tempered until room temperature, for one hour each at seven equidistant temperatures, ranging from $100{ }^{\circ} \mathrm{C}$ up to $700^{\circ} \mathrm{C}$.

The VSI mechanical properties were determined according to its apparent hardness. It was determined in accordance with the standard ASTM E 10-01 [7]. This test method covers the determination of the Brinell hardness of metallic materials.

The VSI apparent hardness was determined according to the Brinell model with a sphere of $\varnothing 2.5$ $\mathrm{mm}$ and a load of $187.5 \mathrm{kgf}$. Moreover, it can be represented as an international standard abbreviation by HB 2.5 / 187.5 .

\section{Results and discussion}

The Brinell hardness (HB 2.5/187.5) variation for the VSI considering the as sintered, air quenched and double tempered, one hour each at the specified temperature and air-cooled, ranging from $100^{\circ} \mathrm{C}$ up to $700{ }^{\circ} \mathrm{C}$, is shown in Tab. 1 . It can be observed a substantial variation of the components hardness. According to the VSI final commercial application requirements, the hardness should be between $370 \mathrm{HB}$ until $410 \mathrm{HB}(2.5 / 187.5)$. It also shows that the powders mixtures and heat treatments that resulted in hardness between 370 and $410 \mathrm{HB}$, is the VSI obtained with Alloy 1 (AISI M2 powder mixture) air quenched and double tempered at $600{ }^{\circ} \mathrm{C}$.

Table 1. Brinell hardness (HB 2.5 / 187.5) variation for the Alloy 1 (AISI M2 high-speed steel powder) mixture of VSI as sintered, quenched $\left(1,150{ }^{\circ} \mathrm{C}\right.$ quenched in air) and double tempered at seven equidistant different temperatures.

\begin{tabular}{|c|c|c|}
\hline & & Alloy 1 \\
\hline \multirow{8}{*}{ 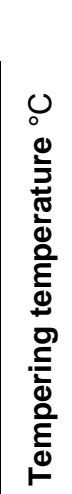 } & As sintered & $366 \pm 4$ \\
\hline & 100 & $345 \pm 5$ \\
\hline & 200 & $380 \pm 5$ \\
\hline & 300 & $327 \pm 3$ \\
\hline & 400 & $318 \pm 2$ \\
\hline & 500 & $425 \pm 8$ \\
\hline & 600 & $392 \pm 1$ \\
\hline & 700 & $299 \pm 1$ \\
\hline
\end{tabular}




\section{References}

\section{Conclusions}

The air quenching, despite the low cooling rate, gave the desired variation of properties and phase transformations.

Air quenching and double tempering the valve seat inserts in different temperatures showed to be a powerful tool regarding the desired microstructural and mechanical properties variation.

Despite many different phases present at the microstructure, the AISI M2 high-speed steel seems to be the element with most influence on it, thus, keeping the good properties of the components.

\section{Acknowledgments}

The authors want to thank CAPES and CNPq for the financial support. In addition, General Motors South America, Höganäs and Group Combustol \& Metalpó for materials and equipment supply.
[1] CHANG, I.; ZHAO, Y. Advances in powder metallurgy: properties, processing and applications. Woodhead Publishing, UK, 2013.

[2] ASM International Handbook Committee, Metals Handbook Vol. 7. Powder Metal Technologies and Applications. ASM International, 10th ed., 1999 (electronic version).

[3] SANTOS, I. P. Processing and characterization of sintered steels for use in valve seat inserts. Dissertation (Master in Nuclear Technology). São Paulo: IPEN-USP; 2014. (In Portuguese).

[4] GOMES, M. P.; SANTOS, I. P.; MUCSI, C. S.; COLOSIO, M. A.; ROSSI, J. L. In Proceedings of the VII Encontro Científico de Física Aplicada, Mai 11-13; Serra, ES, Brazil, p. 59-61, 2016.

[5] GOMES, M. P.; SANTOS, I. P.; COUTO, C. P.; MUCSI, C. S.; COLOSIO, M. A.; ROSSI, J. L. In Proceedings of the VIII Conferência Brasileira sobre Temas de Tratamento Térmico, May 21-24, Indaiatuba, SP, Brazil, p. 133-140, 2017.

[6] KRAUSS, G. Steels: heat treatment and processing principles. ASM International, 1990.

[7] American Society for Testing and Materials (ASTM). Standard test method for: Brinell hardness of metallic materials. ASTM E 10-01, ASTM International, 2004. 